\title{
Delayed diagnosis of isolated jejunal perforation following blunt abdominal trauma
}

\author{
Künt karın travması sonrası gelişen izole jejunum perforasyonu tanısında \\ gecikme
}

\author{
Kadir Koray Baş*, Hasan Besim \\ Department of General Surgery (Assist. Prof. K. K. Baş, MD, Prof. H. Besim, MD), Near East \\ University Faculty of Medicine, Nicosia, TRNC.
}

\begin{abstract}
Isolated jejunal perforation due to blunt abdominal trauma is a rare clinical condition and it may be easily unnoticed during the first examination or radiological studies, so that a delay in diagnosis is common. We present a case with isolated jejunal perforation after a blunt abdominal trauma which was not diagnosed at the first examination in the emergency department. The initial radiological studies were also normal and at the observation period small intestinal injury was diagnosed eight hours later with serial physical examinations and control radiological studies. Because diagnosing an isolated small intestinal injury is still a medical challenge, medical observation is a lifesaving measure.
\end{abstract}

Keywords: Abdominal blunt injuries; intestinal perforation, jejunum

\section{Özet}

Künt karın travması sonrası gelişen izole jejunum perforasyonu, ilk muayene ve radyolojik değerlendirmelerle kolayca fark edilemeyen nadir bir durumdur. Bu sunumda; acil servise başvuran ve ilk muayene, radyolojik incelemeleri normal değerlendirilen künt karın travmalı bir olgunun müşahede altında iken tekrarlanan fizik muayene ve kontrol görüntülemeleri ile 8 saat sonra tespit edilen izole jejnum perforasyonu sunulmuştur. $\mathrm{Bu}$ tür travma olgularının gözlem altında tutulması benzer hayati sorunların tespiti için son derece önemlidir.

Anahtar sözcükler: Künt karın yaralanmaları, barsak perforasyonu, jejunum

Geliş tarihi/Received: April 11, 2012; Kabul tarihi/Accepted: November 12, 2012

\section{*Corresponding author:}

Kadir Koray Baş, MD, Department of General Surgery, Near East University Faculty of Medicine, Nicosia, TRNC. E-mail: drkoraybas@yahoo.com

\section{Introduction}

Isolated jejunal perforation due to blunt abdominal trauma is a rare but life-threatening clinical situation because it can easily go unnoticed at the first examination and radiological studies [1]. Timely diagnosing of an intestinal perforation can be made by clinical suspicion, evaluating the history and mechanism of the trauma, serial physical examinations with laboratory and radiological studies under medical observation [2]. We present a rare case of an isolated jejunal perforation due to blunt abdominal trauma which could be diagnosed eight hours after his admission to the hospital.

\section{Case report}

A 44 year-old man was admitted to the emergency department (ED) of Near East University Hospital with a history of trauma to his lower back after being squeezed into a wall by the head butt of a bull in a farm.. This was the only reported history and mechanism of the injury. On admission to the ED, two hours after the injury, the patient 
was in a stable clinical situation with a Glasgow coma scale score of 15 . Vital signs of the patient were blood pressure 130/85 $\mathrm{mmHg}$, cardiac pulse rate 88 beats/min, body temperature $36.5^{\circ} \mathrm{C}$, respiratory rate 24 breaths/min. By physical examination, he was observed to have erythema and swelling over the right lumbar area and a superficial abrasion on the right crista iliaca anterior superior. The patient was found to have normal bowel sounds in all quadrants and lung sounds bilaterally by auscultation. The only positive finding was tenderness on the right lumbar area and right posterior wall of the chest by palpation. There was mild tenderness on the right upper quadrant but no guarding. There was no pathological finding or hemorrhage in distal part of rectum with digital rectal examination. Macroscopic hemorrhage was not observed with urinary catheterization. Laboratory routine blood tests (complete blood count and biochemistry) were significant for only white blood cell (WBC) count of $16.000 / \mathrm{mm}^{3}$. A plain chest $\mathrm{X}-$ ray film showed no free air under the diaphragm. A computed tomography (CT) scan of the abdomen also demonstrated no free-air or fluid intraperitoneally or extraperitoneally (Figure 1). The patient was admitted to the ward for medical observation with serial physical examinations.

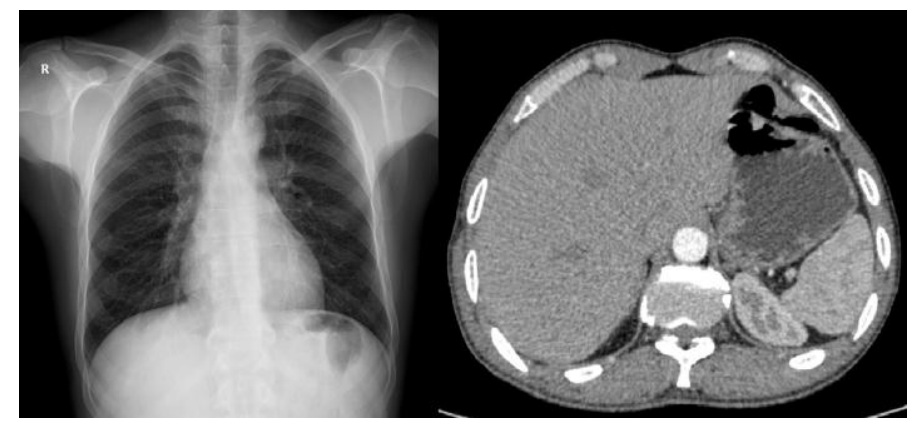

Figure 1. The initial chest $\mathrm{x}$-ray and CT scan image with normal findings.

Eight hours later, the patient had increasing abdominal pain, vomiting and fever. It was determined that he had diffuse abdominal tenderness with rebound pain and guarding on all quadrants by physical examination. WBC count raised up to $18.500 / \mathrm{mm}^{3}$ and control abdominal CT scan demonstrated free-air and fluid in the abdominal cavity but no evidence of any solid organ injury (Figure 2). Subsequently the patient was taken to the operating room and exploratory laparotomy was performed with an initial diagnosis of hollow visceral perforation. During the exploration, the only injury was a round shaped perforation $1 \mathrm{~cm}$ in diameter on the anti-mesenteric side of the jejunum which was located $100 \mathrm{~cm}$ distally from the ligament of Treitz and approximately $500 \mathrm{cc}$ amount of bilestained free fluid in the peritoneal cavity was found. The rest of the intraperitoneal organs were normal. The ruptured site of jejunum was sutured primarily and the peritoneal cavity was drained with Jackson-Pratt drain after through irrigation with normal saline. Postoperative period was uneventful. Oral intake was started on the third day and the patient was discharged on the sixth day after the operation in good health. 


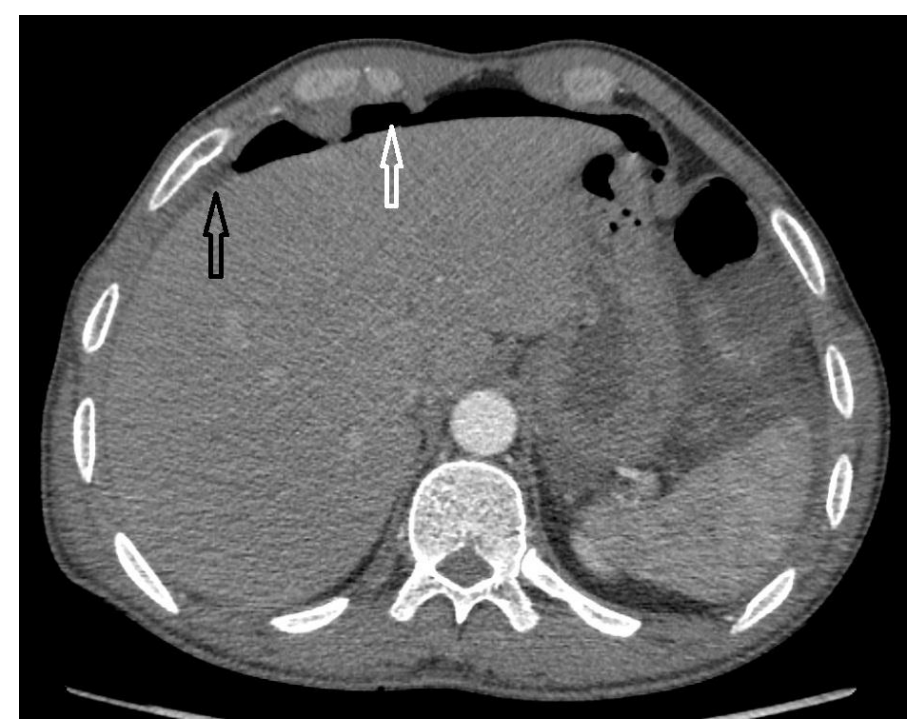

Figure 2. Control CT scan image with intraperitoneal free-air (white arrow) and free-fluid (black arrow).

\section{Discussion}

Isolated small intestinal perforation due to blunt trauma is an extremely rare clinical situation. According to a large multi-institutional study by EAST Multi-Institutional Hollow Viscus Injury Research Group, the incidence is calculated as only $0.3 \%$ within all blunt trauma admissions [3]. Unlike patients with penetrating injury, the patient with blunt trauma rarely presents with clinical evidence of a perforated hollow viscus. This can cause a delay in diagnosis and may result with morbidity or mortality due to complications. According to the same research group, a small bowel injury significantly increases the complication and mortality rates compared with non-small bowel injury group in patients with blunt trauma [4]. This type of intestinal perforations are known as "blowout" perforations because they are often located on the anti-mesenteric side of the intestine and probably resulting from a sudden increase in intraluminal pressure in a fluid or air-filled segment of intestine. Small intestinal injury after a blunt abdominal trauma is still a challenge for emergency department physicians and even for surgeons. Physical examination alone is not sufficient for the diagnosis. Findings of the peritonitis following small bowel perforation may be insidious because of the seeping content is low irritant with low bacterial count [5]. There are no clinically dependable signs or symptoms as well as no free-air under the diaphragm on plain chest X-ray in all cases [6].

There are some diagnostic tools that can be used for the right diagnosis such as focused abdominal sonography for trauma (FAST), CT scanning and diagnostic peritoneal lavage (DPL). DPL was the most common diagnostic method in the 80's and 90's, but with the improving quality of CT scan imaging as a non-invasive technique and an understanding that the routine use of peritoneal lavage in stable trauma patients often leads to unnecessary laparotomies, it is rarely used today [7]. FAST is a useful tool for the diagnosis of the solid organ injuries and detect free-fluid in abdomen but it is not adequate to determine small intestinal injury due to blunt trauma with only a positive predictive value of $38 \%$ [4]. CT scanning is now used as a golden standard with a sensitivity of $92 \%$ and specificity of $94 \%$ for diagnosis of blunt trauma [8]. However, for isolated small bowel perforation, the presence of free-fluid alone on initial CT scan without evidence of solid organ injury was associated with a $30.5 \%$ incidence of perforated small bowel injury [4].

Diagnostic laparoscopy, as a relatively new method for emergency cases, may be used for diagnosis as well as treatment in the same session [9]. Early diagnosis and treatment of 
small bowel perforation can significantly reduce morbidity and mortality of patients. Watts et al. state that the mortality rate is $16 \%$ in patients whose operative treatment is delayed more than 24 hours due to perforated blunt small bowel injury [3]. Because of potential delays in clinical presentation, all patients who have had an abdominal blunt trauma should have several hours of medical observation. During this time, serial clinical examinations and proper laboratory studies must be done, in case of suspicion of any hollow viscus injury radiological studies must be renewed.

In conclusion, the diagnosis of isolated small intestinal perforation due to blunt abdominal trauma is still challenging. Clinical suspicion is the most important step for not missing this insidious and potentially life threatening situation. For optimal outcomes, a multi-modal approach must be used as taking the mechanism of the injury, repeated physical examinations with appropriate laboratory and radiological studies while the patient is still under medical observation.

\section{Acknowledgements}

The authors would like to acknowledge Nigel Coxon and Catherine Hayes, native speakers of English, who volunteered their time and effort to edit this text.

\section{References}

1. Kılbaş Z, Demirbaş S, Coşkun AK, Kozak O, Tufan T. Künt travmaya bağl1 (inek süsmesi) geç dönem ortaya çıkan jejunum perforasyonu: Olgu sunumu. Bakırköy T1p Dergisi 2012; 8: 50-2.

2. Abbasakoor F, Vaizey C. Pathophysiology and management of bowel and mesenteric injuries due to blunt trauma. Trauma 2003; 5: 199-214.

3. Watts DD, Fakhry SM; EAST Multi-Institutional Hollow Viscus Injury Research Group. Incidence of hollow viscus injury in blunt trauma: an analysis from 275,557 trauma admissions from the East multi-institutional trial. J Trauma 2003; 54: 289-94. Erratum in: J Trauma 2003; 54: 749.

4. Fakhry SM, Watts DD, Luchette FA; EAST Multi-Institutional Hollow Viscus Injury Research Group. Current diagnostic approaches lack sensitivity in the diagnosis of perforated blunt small bowel injury: analysis from 275,557 trauma admissions from the EAST multi-institutional HVI trial. J Trauma 2003; 54: 295 306.

5. Parvin S, Smith DE, Asher WM, Virgilio RW. Effectiveness of peritoneal lavage in blunt abdominal trauma. Ann Surg 1975; 181: 255-61.

6. Schenk WG 3rd, Lonchyna V, Moylan JA. Perforation of the jejunum from blunt abdominal trauma. J Trauma 1983; 23: 54-6.

7. Powell RW, Green JB, Ochsner MG, Barttelbort SW, Shackford SR, Sise MJ. Peritoneal lavage in pediatric patients sustaining blunt abdominal trauma: a reappraisal. J Trauma 1987; 27: 6-9.

8. Sherck J, Shatney C, Sensaki K, Selivanov V. The accuracy of computed tomography in the diagnosis of blunt small-bowel perforation. Am J Surg 1994; 168: 670-5.

9. Dente M, Santi F, Solinas L, Bagarani M. Laparoscopic diagnosis and management of jejunal perforation resulting from accidental toothpick ingestion. Am Surg 2009; 75: 178-9. 